Ilmu Pertanian (Agricultural Science)

Vol. 3 No. 2 August, 2018: 72-81

Available online at http://journal.ugm.ac.id/jip

DOI: doi.org/10.22146/ipas.33593

\title{
GGE Biplot Analysis of Multi-Environment Yield Trials in Soybean Promising Lines
}

\author{
Ayda Krisnawati*, M. Muchlish Adie \\ Indonesian Legumes and Tuber Crops Research Institute \\ Jl. Raya Kendalpayak KM 8 Malang 65101, East Java, Indonesia \\ *Corresponding email: my_ayda@yahoo.com
}

\begin{abstract}
Soybean in Indonesia is grown in diverse agro-ecological environments. The performance of soybean yield often varies due to significant genotype $\times$ environment interaction (GEI), therefore the yield stability of performance is an important consideration in the breeding program. The aim of the research was to exploring the GEI pattern and yield stability of soybean promising lines in the tropics using GGE (Genotype and Genotype by Environment Interaction) biplot method. A total of 16 soybean promising lines were evaluated in ten environments during 2016 growing season. The experiment was arranged in a randomized completely block design with four replicates. The analysis of variance revealed that environments (E) explained the highest percentage of variation $(51.45 \%)$, meanwhile the genotypes $(\mathrm{G})$ and genotype $\times$ environment interactions (GEI) contributed for $3.24 \%$, and $14.59 \%$ of the total variation, respectively. Seed yield of 16 soybean promising lines ranged from 2.41 to 2.83 t.ha $^{-1}$ with an average of 2.74 t.ha ${ }^{-1}$. Joint effects of genotype and interaction $(\mathrm{G}+\mathrm{GE})$ which was partitioned using GGE biplot analysis showed that the first two components were significant, explaining $60.88 \%$ (37.89\% PC1 and 22.98 \% PC2) of the GGE sum of squares. Indonesia can be divided into at least four putative mega environments for soybean production. The GGE biplot identified G10 as high yielding and stable promising line, thus recommended to be developed in multi-environment in tropical regions of Indonesia.
\end{abstract}

Keywords: GGE biplot, high yield, soybean, stable.

\section{INTRODUCTION}

Soybean, one of the major staple foods in Indonesia, is grown in diverse agro-ecological conditions. Soybean is planted in the wetland (paddy field/upland) after one or two planting seasons of rice, or in dry land (lowland) which planted in the beginning of the rainy season. However, the largest area of soybean cultivation is in the lowland during the second dry season (June/July-September/October). Thus, a large variation appears in soybean yield level could be due to the genotype by environment interaction (GEI).

GEI is a common phenomenon in a multi-environment yield trials (Hagos and Abbay, 2013), and can be defined as the failure of genotypes to achieve consistent performance (stability) across different environments (Baker, 1988). It has been reported that the GEI may reduces the correlation between phenotype and genotype as well as complicates in breeding program, such as during the testing and selection of superior genotypes (Rao et al., 2011; Atnaf et al., 2013; Hagos and Abbay, 2013; Kumar et al., 2014). The significant presence of GEI has been showed in previous studies in rice (Samonte et al., 2005), sorghum (Rakshit et al., 2010), maize (Tonk et al., 2011), potato (Gedif et al., 2014), and soybean (Kandil et al., 21012; Adie et al., 2013).

Multi-environment yield trials are widely used to identify high-yielding and stable genotypes across a wide range of environments (Fan et al., 2007). Seed yield, an economically most important trait in soybean, is a quantitative trait which controlled by many genes and a product of interaction between genotypes and environment (Liu \& Herbert, 2002; Abady et al., 2012; Choi et al., 2016). Environmental factors, such as growing season, type of soil, planting pattern, and different elevations affect the adaptation of soybean varieties in Indonesia (Adie et al., 2015; Kuswantoro, 2016). Environmental changes may affect both crop growth and yield due to significant GEI (Luo et al., 
2015).

Various statistical techniques have been developed to explore the patterns of GEI from multi-environmental yield data trial, such as joint regression (Finlay and Wilkinson, 1963; Eberhart and Russel, 1966; Perkins and Jinks, 1968), Additive Main Effect and Multiplicative Interaction (AMMI) (Gauch, 1992), and Genotype plus Genotype $\times$ Environment interaction (GGE) (Yan et al., 2000). In this study, GGE biplot was used to display graphical examination the GEI pattern of multi-environmental yield data (Yan et al., 2000). According to Fan et al., (2007), GGE can be used to identify the least discriminating locations and representing test locations. Several studies also revealed that GGE provides mega-environment analysis through the 'Which-won-where' pattern' biplot, genotype evaluation (mean vs. stability), and test environment evaluation which provides the most desirable test location (discriminating power vs. representativeness) (Yan et al., 2007; Amira et al., 2013). Furthermore, GGE analysis was based on principal component analysis (PCA) which useful to fully explore multi-environment trials (Yan et al., 2001).

GGE has been recognized and applied as a popular method to analyse and visualize the pattern of GEI in multi-environment yield trials in various crops (Brar et al., 2010; Jandong et al., 2011; Ullah et al., 2012; Bhartiya et al., 2017). However, the use of GGE biplot in Indonesia have not very much implemented, particularly as a tool for determining the mega environments, the best genotype in each location, and stability of soybean genotypes. The research materials used in this study were promising lines derived from crossing and followed by preliminary and advanced yield trials to obtain genotypes with high and stable productivity (yield) which in accordance with farmer's preferences. During the advanced yield trials, the fourteen promising lines have relatively exhibited high yield performance (Adie et al., 2014). However, the multi-location trials are required for evaluating the yield stability of each promising line. Therefore, the aims of this study was to exploring the GEI pattern and yield stability of soybean promising lines in the tropics using GGE (Genotype Main Effect and Genotype by Environment Interaction) biplot method.

\section{MATERIALS AND METHODS}

\section{Genetic Materials}

The genetic materials consist of fourteen promising lines and two check varieties i.e., Anjasmoro and Argomulyo are having high yield and well known varieties, were used in this study (Table 1).

\section{Field Trials}

The field trials were conducted at several soybean production centers in Indonesia with different soil types, average annual rainfall, and altitude. The detail description of field trial locations is presented in Table 2 . The study was conducted during the dry season from February to September 2016.

Table 1. Genotype and genotype code in soybean multi location trials at 10 locations

\begin{tabular}{lll}
\hline Code & Genotype & Pedigree \\
\hline G1 & G 511 H/Anjs/Anjs-2-13 & G511H /Anjasmoro//Anjasmoro \\
G2 & G 511 H/Anjs-1-1 & G511H /Anjasmoro \\
G3 & G 511 H/Arg//Arg///Arg-30-7 & G511H /Argomulyo//Argomulyo///Argomulyo \\
G4 & G 511 H/Kaba//Kaba///-4-4 & G511H /Kaba//Kaba \\
G5 & G 511 H/Kaba//Kaba///Kaba///Kaba 16-2 & G511H /Kaba//Kaba//Kaba///Kaba \\
G6 & G 511 H/Anjs/Anjs///Anjs-3-3 & G511H /Anjasmoro//Anjasmoro///Anjasmoro \\
G7 & G 511 H/Anjs/Anjs///Anjs-6-13 & G511H /Anjasmoro//Anjasmoro///Anjasmoro \\
G8 & G 511 H/Anjs//Anjs-1-2 & G511H /Anjasmoro//Anjasmoro \\
G9 & G 511 H/Anjs//Anjs-5-5 & G511H /Anjasmoro//Anjasmoro \\
G10 & G 511 H/Anjs/Anjs///Anjs-6-11 & G511H /Anjasmoro//Anjasmoro///Anjasmoro \\
G11 & G 511 H/Anjs/Anjs///Anjs-8-1 & G511H /Anjasmoro//Anjasmoro///Anjasmoro \\
G12 & G 511 H/Anjs//Anjs-1-3 & G511H/Anjasmoro//Anjasmoro \\
G13 & G 511 H/Anjs//Anjs///Anjs-6-12 & G511H /Anjasmoro//Anjasmoro///Anjasmoro \\
G14 & G 511 H/Anj//Anj///Anj///Anjs-6-8 & G511H /Anjasmoro//Anjasmoro///Anjasmoro///Anjasmoro \\
G15 & Anjasmoro & - \\
G16 & Argomulyo & - \\
\hline
\end{tabular}


Table 2. Location, code and characteristics of the multi-environment trials, February to September 2016

\begin{tabular}{|c|c|c|c|c|c|c|}
\hline No. & Location & Code & SoilType & Land Type & Climatea & $\begin{array}{c}\text { Altitude } \\
\text { (masl) }\end{array}$ \\
\hline 1. & Bojong Pondok Terong, Cipayung, Depok, West Java & E1 & Ultisol & Lowland & $\mathrm{B}$ & 330 \\
\hline 2 & Banaran Wetan, Bagor, Nganjuk, East Java & $\mathrm{E} 2$ & Regosol & Lowland & $\mathrm{E}$ & 5 \\
\hline 3 & Kedunguneng, Bangsal, Mojokerto, East Java & E3 & Gray Grumosol & Lowland & $\mathrm{C} 3$ & 7 \\
\hline 4 & Binangun, Binangun, Blitar, East Java & E4 & Alluvial & Upland & $\mathrm{C} 3$ & 355 \\
\hline 5 & Sumber Banteng, Kejayan, Pasuruan & E5 & Brown Mediteran & Upland & $\mathrm{E}$ & 124 \\
\hline 6 & Tapan Rejo, Muncar, Banyuwangi & E6 & Latosol & Lowland & D2 & 168 \\
\hline 7 & Gambiran, Genteng, Banyuwangi, East Java & E7 & Latosol & Lowland & D2 & 168 \\
\hline 8 & Budeng, Jembrana, Jembaran, Bali & E8 & Alluvial & Lowland & D2 & 74 \\
\hline 9 & Berabah, Kediri, Tabanan, Bali & E9 & Latosol & Lowland & D3 & 20 \\
\hline 10 & Segara Anyar, Pajut, Central Nusa Tenggara & E10 & Regosol & Lowland & $\mathrm{C} 3$ & 24 \\
\hline
\end{tabular}

Remarks: Aclimate type based on Oldeman (1974) climate classification system: $\mathrm{B}=7-9$ wet months, C3 $=5-6$ wet months and 4-6 dry months, D2 = 3-4 wet months and 2-3 dry months, D3 = 3-4 wet months and 4-6 dry months, E $=<3$ wet months; masl $=$ meter above sea level.

\section{Experimental Design and Plant Cultivation}

The experiment was arranged in randomized complete block design with four replications in each location. Unit plot size and planting spacing for each line were $2.0 \mathrm{~m} \times 4.5 \mathrm{~m}$ and $40 \mathrm{~cm} \times 15 \mathrm{~cm}$, respectively. Two seeds per hill were sown and plants were entirely fertilized with $250 \mathrm{~kg} \cdot \mathrm{ha}^{-1}$ Ponska, $100 \mathrm{~kg} \cdot \mathrm{ha}^{-1}$ SP36, and 1 tha $^{-1}$ organic fertilizer after sowing the seeds. Weeds, pests, and diseases were intensively controlled by following common monitoring system. Irrigation was applied to maintain optimum condition for soil field capacity.

\section{Observation and Data Analysis}

Plant height, days to flowering, days to maturity, number of branch per plant, number of node per plant, number of the filled pod, 100 seed weight, and seed yield per plot were observed in this study. The plant height, number of branch per plant, number of node per plant, and number of the filled pod were randomly recorded from 10 sample plants. Seed yield per plot was converted to ton.ha ${ }^{-1}$. Data were analyzed using analysis of variance (ANOVA) using SAS ver. 9.1.3 (SAS, 2007). The GGE analysis was used to determine the effects of GEI on yields. The results of the GGE analysis were visualized in biplot graphs (Yan et al., 2000; Rakshit et al., 2012).

\section{RESULTS AND DISCUSSION}

\section{Analysis of Variance and GGE}

The analysis of variance for seed yield and yield components of the sixteen genotypes tested in ten environments revealed that the mean squares of environments, genotypes, and genotype $\times$ environment interactions (GEI) were highly significant for all the evaluated traits (Table 3), and accounted for $51.45 \%$, $3.24 \%$, and $14.59 \%$ of treatment combination sum of squares, respectively. A highly significant GEI for yield trait indicating the necessity for the further analysis of stability.

The GGE analysis partitioned the sum of squares

Table 3. Analysis of variance for yield and yield components of 16 genotypes in 10 environments

\begin{tabular}{lccccc}
\hline \multirow{2}{*}{ Parameter } & \multicolumn{5}{c}{ Mean Square } \\
\cline { 2 - 6 } & Replication|R & Environment (E) Genotype $(\mathrm{G})$ & $\mathrm{G} \times \mathrm{E}$ & $\mathrm{CV}(\%)$ \\
\hline Days to flowering (day) & $38.3239^{* *}$ & $315.3618^{* *}$ & $219.1983^{* *}$ & $4.7240^{* *}$ & 3.35 \\
Days to maturity (day) & $15.1385 \mathrm{~ns}$ & $78.1243^{* *}$ & $55.6666^{* *}$ & $26.3613^{* *}$ & 4.31 \\
Plant height (cm) & $143.2029 \mathrm{~ns}$ & $6097.5492^{* *}$ & $1623.7875^{* *}$ & $167.5997^{* *}$ & 16.22 \\
Number of branches/plant & $1.1176^{* *}$ & $10.0441^{* *}$ & $5.1976^{* *}$ & $0.9250^{* *}$ & 32.27 \\
Number of node/plant & $22.8506^{* *}$ & $646.3024^{* *}$ & $88.9627^{* *}$ & $14.5185^{* *}$ & 22.83 \\
Number of filled pod/plant & $980.0025^{* *}$ & $7333.8095^{* *}$ & $658.7600^{* *}$ & $110.6048^{* *}$ & 24.15 \\
100 seed weight (g) & $4.2251^{* *}$ & $171.9735^{* *}$ & $8.9358^{* *}$ & $3.2270^{* *}$ & 8.59 \\
Seed yield (ton/ha) & $0.2154^{* *}$ & $11.6502^{* *}$ & $0.4402^{* *}$ & $0.2202^{* *}$ & 12.88 \\
\hline
\end{tabular}

Remarks: $\mathrm{CV}=$ coefficient of variation; $* *=$ significant at $1 \%$ probability level $(\mathrm{p}<0.01)$, ns $=$ not significant 
Table 4. Analysis of variance for GGE

\begin{tabular}{lcccc}
\hline Principal Component & Degree of freedom & Eigen values & Total Eigen values (\%) & Cumulative (\%) \\
\hline Genotipe $(\mathrm{G})$ & 15 & $6.6033^{* *}$ & & \\
$\mathrm{G} \times \mathrm{E}$ & 135 & $29.7347^{* *}$ & & 37.89 \\
PC1a & 23 & $13.7704^{* *}$ & 37.89 & 60.87 \\
PC2b & 21 & $8.3512^{* *}$ & 22.92 & 100 \\
Residual & 91 & 14.2164 & 39.13 & \\
Total eigen valuesc & $980.0025 * *$ & $36.3380 \mathrm{a}$ & & \\
\hline
\end{tabular}

Remarks: $\mathrm{CV}=$ coefficient of variation; $* *=$ significant at $1 \%$ probability level $(\mathrm{p}<0.01)$, ns $=$ not significant

of GEI into nine interaction principal components (PCs), of which the first three PCs was significant. The partitioning of the $\mathrm{G}+\mathrm{GE}$ sum of squares through GGE biplot showed that PC1 and PC2 were $37.89 \%$ and $22.98 \%$ of $\mathrm{G}+\mathrm{GE}$ sum of squares, suggesting significant components (Table 4).

\section{Which-Won-Where Pattern and Mega Environment Classification}

The GGE biplot was used to effectively identify the existing GEI pattern of the data (Fig.1). Polygon views of the GGE biplot showed the mega-environments and their respective highest yield cultivars (Fig. 1), and explicitly exhibited the "which-won-where pattern" as a concise summary of the GEI pattern derived from multi-environment yield trial data set.

In the present study, seven rays in Figure 1, the biplot was divided into seven sectors and the environments only into four of them. The rest three sectors in the polygon had no test environment. Four environments (E3, E7, E9, and E10), fell into the first sector or mega-environment. The first mega-environment and the vertex genotype were G10, suggesting this is the highest-yielding genotype for these four environments. The second mega-environment contained one environment (E8), and the vertex genotype was G7, suggesting this is the high-yielding genotype in E8. Other genotypes which located at this second megaenvironment (G12 and G14) were also well adapted. Two environments (E1 and E6) fell into the third mega-environment. The vertex genotype for this mega-environment was G4, suggesting this genotype is the highest-yielding genotype for those environments. G11 and G13 which were also located at the similar sector, indicated those genotypes well performed at those environment. The fourth mega-environment contained three environments (E2, E4, and E5) with the two vertexes genotypes were G1 and G16. For this mega-environment, G1 had similar high yield with G16, and other genotypes (G5 and G8) also have good adaptation in those three environments. Vertex genotypes G6 and G3 were not winners at any test environment. Genotypes which fall in sectors where there

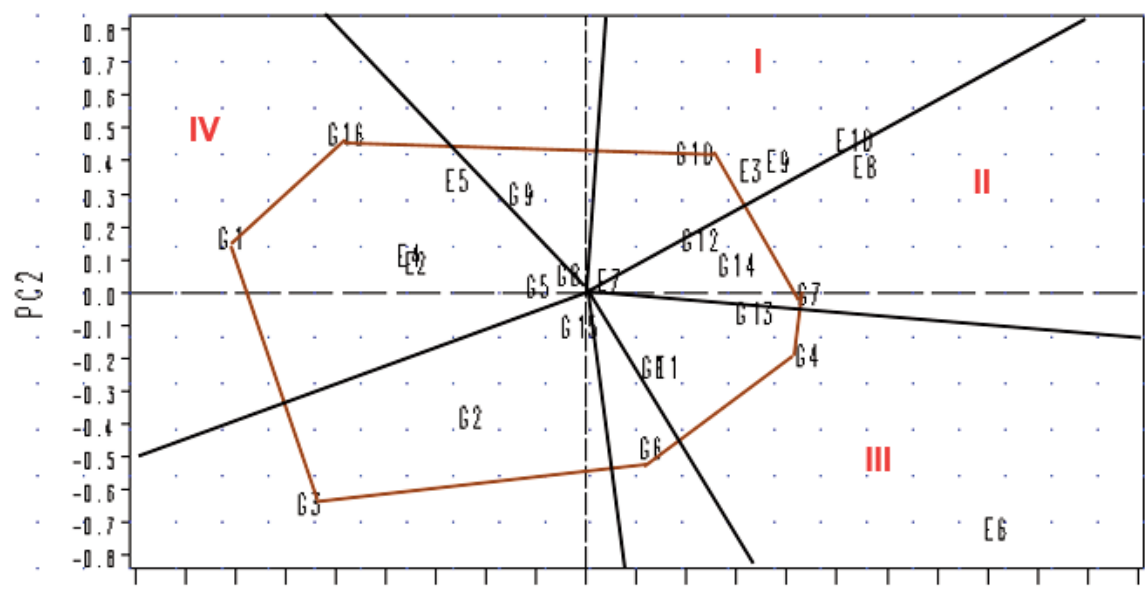

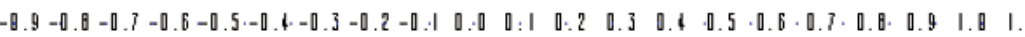

$\mathrm{PCl}$

Figure 1. Polygon views of the GGE-biplot for the which-won-where pattern for genotypes and environments. Genotypes and environments code refer to Table 1 and Table 2, respectively. $\mathrm{I}$ = first mega-environment, II = second mega-environment, III $=$ third mega-environment, IV = fourth mega-environment 


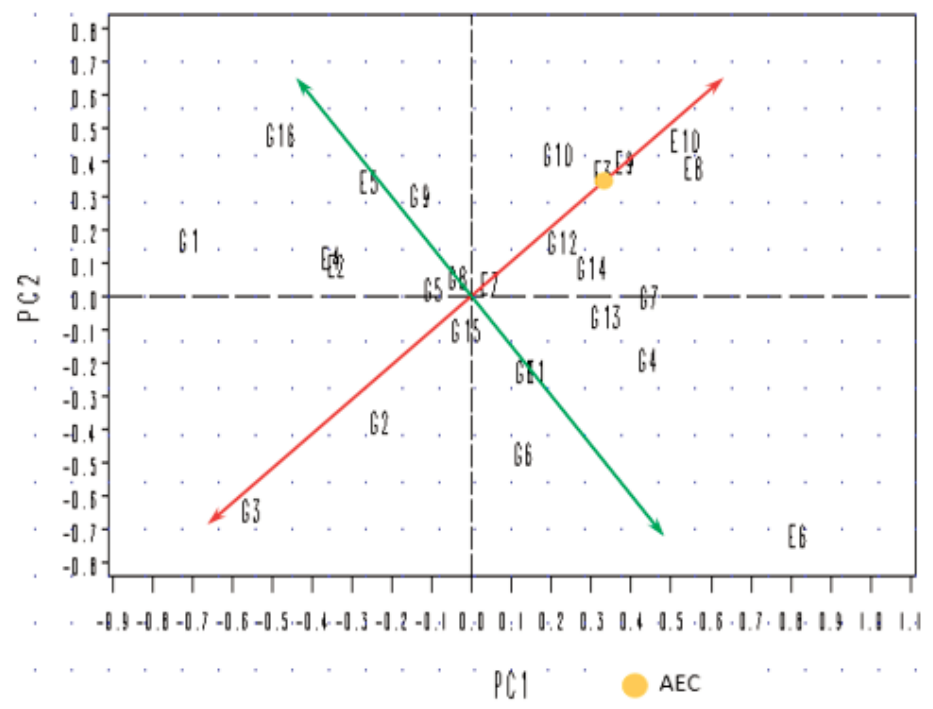

Figure 2. Polygon views of the GGE-biplot for the which-won-where pattern for genotypes and environments. Genotypes and environments code refer to Table 1 and Table 2, respectively. $I=$ first megaenvironment, II = second mega-environment, III = third megaenvironment, IV = fourth mega-environment

Table 5. Seed yield of 16 soybean genotypes planted in ten environments

\begin{tabular}{|c|c|c|c|c|c|c|c|c|c|c|c|}
\hline \multirow{2}{*}{ Code $^{a}$} & \multicolumn{10}{|c|}{ Seed yield $\left(\mathrm{t} \mathrm{ha}^{-1}\right)$} & \multirow{2}{*}{ Mean } \\
\hline & E1 & E2 & E3 & $\mathrm{E} 4$ & E5 & E6 & E7 & $\mathrm{E} 8$ & E9 & E10 & \\
\hline$\overline{\mathrm{G} 1}$ & 2.19 & 3.18 & 2.88 & 3.32 & 2.69 & 2.02 & 2.45 & 2.79 & 3.04 & 2.83 & 2.74 \\
\hline $\mathrm{G} 2$ & 2.14 & 3.00 & 2.84 & 3.06 & 2.18 & 2.77 & 2.15 & 2.81 & 2.78 & 3.05 & 2.68 \\
\hline G3 & 1.97 & 2.82 & 2.58 & 2.90 & 1.74 & 2.39 & 1.77 & 2.74 & 2.87 & 2.33 & 2.41 \\
\hline G4 & 2.44 & 2.64 & 3.28 & 2.75 & 1.90 & 3.00 & 2.27 & 3.25 & 3.32 & 3.25 & 2.81 \\
\hline G5 & 2.01 & 2.62 & 2.85 & 2.72 & 2.30 & 2.39 & 2.06 & 3.03 & 3.15 & 3.23 & 2.64 \\
\hline G6 & 2.49 & 2.94 & 2.80 & 3.03 & 2.14 & 3.16 & 2.06 & 2.89 & 2.94 & 3.37 & 2.78 \\
\hline G7 & 2.12 & 2.58 & 3.05 & 2.67 & 2.06 & 2.88 & 2.12 & 3.50 & 3.26 & 3.45 & 2.77 \\
\hline G8 & 2.32 & 2.90 & 3.04 & 3.03 & 2.53 & 2.66 & 2.38 & 3.07 & 3.32 & 3.12 & 2.83 \\
\hline G9 & 1.84 & 2.81 & 3.19 & 2.88 & 2.39 & 2.28 & 2.02 & 3.07 & 3.19 & 3.34 & 2.70 \\
\hline G10 & 2.14 & 2.79 & 3.29 & 2.87 & 2.38 & 2.46 & 2.03 & 3.49 & 3.35 & 3.52 & 2.83 \\
\hline G11 & 2.25 & 2.73 & 3.09 & 2.84 & 2.30 & 2.96 & 2.41 & 3.07 & 3.11 & 3.11 & 2.79 \\
\hline G12 & 1.81 & 2.91 & 2.97 & 3.01 & 1.82 & 2.65 & 2.27 & 3.50 & 3.52 & 3.32 & 2.78 \\
\hline G13 & 2.24 & 2.82 & 3.17 & 2.90 & 1.86 & 2.87 & 2.45 & 3.41 & 3.44 & 3.13 & 2.83 \\
\hline G14 & 2.22 & 2.75 & 3.29 & 2.85 & 2.22 & 2.82 & 1.75 & 3.26 & 3.52 & 3.27 & 2.80 \\
\hline G15 & 2.13 & 2.69 & 3.23 & 2.79 & 2.46 & 2.71 & 2.50 & 3.16 & 2.92 & 2.92 & 2.75 \\
\hline G16 & 2.08 & 3.16 & 3.13 & 3.28 & 2.19 & 1.77 & 2.10 & 3.11 & 3.19 & 3.21 & 2.72 \\
\hline Mean & 2.15 & 2.83 & 3.04 & 2.93 & 2.20 & 2.61 & 2.17 & 3.13 & 3.18 & 3.15 & 2.74 \\
\hline
\end{tabular}

Remarks: a'Genotypes and environments code refer to Table 1 and Table 2, respectively.

were no locations at all, showed that those genotypes were poorly adapted in all tested environments.

\section{The Performance of Yield and Yield Components} and Stability of Genotypes

Yield performance and stability of soybean genotypes were graphically visualized through GGE biplot (Fig. 2). This can be evaluated by average environment coordination (AEC) method (Yan, 2001; Yan, 2002). In this biplot graph, the AEC was indicated by a yellow circle, which is defined by the average of $\mathrm{PC} 1$ and $\mathrm{PC} 2$ scores of all environments. A straight (red) line passing through AEC with the biplot origin is AEC abscissa, and point towards higher mean values (Farshadfar et al., 2012). A straight (green) line through the origin and perpendicular biplot is AEC ordinate. Directions to the AEC ordinate that move away from the origin biplot showed a lower stability or greater GEI effect. AEC ordinate 
Table 6. Overall yield and agronomic means of 16 soybean genotypes planted in ten environments.

\begin{tabular}{|c|c|c|c|c|c|c|c|}
\hline \multirow{2}{*}{ Code $^{h}$} & \multicolumn{7}{|c|}{ Seed yield $\left(\mathrm{t} \mathrm{ha}^{-1}\right)$} \\
\hline & DTM $^{\mathrm{a}}$ & $\mathrm{PH}^{\mathrm{b}}$ & $\mathrm{NOB}^{\mathrm{c}}$ & $\mathrm{NON}^{\mathrm{d}}$ & $\mathrm{NOP}^{\mathrm{e}}$ & $\mathrm{SW}^{\mathrm{f}}$ & Yield $^{g}$ \\
\hline$\overline{\mathrm{G} 1}$ & 80 & 66.68 & 2.54 & 15.21 & 39.56 & 17.55 & 2.74 \\
\hline $\mathrm{G} 2$ & 82 & 60.40 & 2.46 & 13.51 & 44.07 & 16.34 & 2.68 \\
\hline G3 & 79 & 64.79 & 2.66 & 13.59 & 36.54 & 15.85 & 2.41 \\
\hline G4 & 79 & 61.70 & 2.92 & 17.10 & 38.78 & 16.56 & 2.81 \\
\hline G5 & 80 & 76.43 & 2.04 & 16.68 & 44.98 & 16.64 & 2.64 \\
\hline G6 & 80 & 50.23 & 2.43 & 13.69 & 37.99 & 16.40 & 2.78 \\
\hline G7 & 81 & 68.91 & 2.63 & 14.36 & 43.73 & 15.84 & 2.77 \\
\hline G8 & 81 & 70.61 & 3.13 & 16.93 & 49.49 & 16.08 & 2.84 \\
\hline G9 & 80 & 64.17 & 1.85 & 13.71 & 37.20 & 16.46 & 2.70 \\
\hline G10 & 79 & 58.83 & 2.77 & 13.84 & 38.90 & 16.99 & 2.83 \\
\hline G11 & 82 & 63.99 & 2.03 & 12.97 & 44.69 & 16.09 & 2.79 \\
\hline G12 & 80 & 55.17 & 2.18 & 12.70 & 43.27 & 15.86 & 2.78 \\
\hline G13 & 80 & 66.33 & 2.96 & 14.81 & 45.69 & 16.05 & 2.83 \\
\hline G14 & 81 & 66.71 & 2.30 & 13.04 & 39.09 & 16.12 & 2.79 \\
\hline G15 & 80 & 69.89 & 2.69 & 15.69 & 48.10 & 15.76 & 2.75 \\
\hline G16 & 78 & 59.66 & 2.49 & 12.84 & 38.56 & 16.17 & 2.72 \\
\hline Mean & 80 & 64.03 & 2.50 & 14.41 & 41.91 & 16.30 & 2.74 \\
\hline
\end{tabular}

split genotypes with below the general average yield from those of above the general average yield.

Accordingly, the high yielding genotypes towards the upper right of AEC abscissae, such as G10, G12, G13, and G14. On the contrary, genotypes towards the lower left of AEC abscissa showed the low average yield. In this study, G8 showed the highest stability, followed by G12, G15, G5, and G10. Among the stable genotypes, G10 and G8 were the best performing genotypes in terms of seed yield, followed by G13 and G14.

The soybean seed yields of 16 genotypes planted in ten environments were presented in Table 5. The average seed yield in ten environments was ranged from 2.41 to 2.83 ton.ha $^{-1}$ with an average of 2.74 ton.ha ${ }^{-1}$. The high yielding genotypes were G8, G10, and G13. When we summarized both the yield performance and the yield stability genotypes, G8 and G10 were stable genotypes with high average yield. Nevertheless, G10 produced the highest yield in four environments, whereas G8 never won at all environments (Table 5). Furthermore, G8 was stable andconsistently had lower yield across environments than G10, thus, it could be discarded. Two genotypes, i.e., G13 and G14, were also discarded due to unstable even though it had high average yield. The other stable genotypes (G12, G15, and G5) produced a relatively low yield.

Table 6 presented the overall means of yield and yield components of 16 soybean genotypes in ten environments. The days to maturity of all tested genotypes consisted of early maturity $(<80$ days $)$ and medium maturity ( $80-90$ days). The seed size of all tested genotypes was categorized as large seeded size ( $>14 \mathrm{~g} / 100$ seed). Genotype 10, the stable and highest yielding genotype, had characteristics of early days to maturity (79 days) and large seed size $(16.99 \mathrm{~g} / 100$ seed $)$.

\section{Discussion}

Soybeans are planted in various agro-ecologies. Therefore, yield stability of a cultivar across a wide range of production environments is one of the farmer's preferences in Indonesia. In this study, the significance level of probability for seed yield from the analysis of variance showed the extended of genetic diversity in the material selection or wide diversity between the parental materials used in this study. A highly significant of the GEI for yield suggests that some genotypes were more stable than others across environments (Alghamdi, 2009).

The genotype $(\mathrm{G})$ effect was small in genotypic variation, whereas environment (E) and GEI explains most of the variation. The E showed $51.45 \%$ of the variation which is more than three times of the GEI effects of the total variation, whereas the GEI accounted about $14.59 \%$ of the variation which is more than four times of the $\mathrm{G}$ effects. According to Kaya et al., 
(2006), a large sum of squares for environments indicates the presence of variation in the test environments. The results of this study imply that environment and GEI are important in controling the expression of yield trait (Gedif et al., 2014). Similar findings in the same crop were also obtained in various studies (Asfaw et al., 2009; Gurmu et al., 2009; Bueno et al., 2013; Atnaf et al., 2013; Jandong et al., 2011; Bhartiya et al., 2017).

The large GEI effect found in this study proposes the differential yield performance among soybean genotypes across testing environments or the possible existence of different mega-environments with different winning genotypes (Yan and Kang, 2003). In this study, the seven environments out of ten had different winner genotypes. Yan and Kang (2003) reported that seed yield across environments could serve as sufficient measurement of genotypic performance when the genotype by environment interaction was absent, but in the presence of the GEI effect could complicate the selection process of superior genotypes and also may reduce the selection efficiency in breeding programs (Gauch, 2006; Rao et al., 2011; Kumar et al., 2014).

The GGE refers to the genotype main effect $(\mathrm{G})$ and the genotype $\times$ environment (GE) interaction. The $G$ and GEI are the most important sources of variation for cultivar evaluation in a multi-environment trials (Yan et al., 2007; Fan et al., 2007). In the GGE biplot, the complex GEI is simplified in different Principal Components (PCs) and the data are graphically visualized against various PCs. PC1 approximates the genotype main effects (mean performance), whereas the PC2 approximates the GEI effect (a measure of instability) for each genotype (Yan and Tinker, 2006). The soybean genotypes mean performance and stability were graphically visualized through GGE biplot (Fig 1, Fig 2). However, the GGE biplots are essential tools for addressing the mega-environment issue, by showing which cultivar won in which environments, and thus an effective visual tool in mega-environment identification (Yan et al., 2000).

The visualization of which-won-where patterns of multi-environment yield trials identifies the existence of different mega-environments in soybean growing regions (Fig. 1). The "which-won-where pattern" is one of most attractive GGE biplot feature which able to graphically address essential concepts, such as megaenvironment differentiation and specific adaptation of a genotype (Rakshit et al., 2014). Figure 1 presents a polygon view of "which-won-where pattern" of sixteen soybean genotypes tested at ten environments. The polygon of the GGE-biplot for the which-wonwhere pattern is formed by connecting the vertex of the farthest genotypes from the biplot origin in a way that all other genotypes fall inside the polygon (Cravero et al., 2010). The vertex genotype(s) for each sector has (have) higher (sometimes the highest) yield than the others in all environments that fall in the sector (Yan, 2002).

The polygon view of this biplot (Fig.1) showed that the test environments and genotypes fell into four and seven sectors, respectively. Three of the sectors in the polygon had no test environment, hence there were four constructed mega-environments with different "winning" genotypes. The term mega-environment defines the partition of a crop growing region into different target zones. It consists of an irregular polygon and lines drawn from the biplot origin (Gauch and Zobel, 1996). According to Yang and Tinker (2006), the most responsive genotypes were located at the vertexes of the polygon, since they have the longest distance from the origin in their direction. Thus, the G10 was the most responsive genotype in the E3, E7, E9, and E10. Furthermore, the G7 was the most responsive genotype in $\mathrm{E} 8$, whereas the $\mathrm{G} 4$ was the most responsive genotype in E1 and E6. In addition, G1 and G6 were two of the most responsive genotypes in $\mathrm{E} 2, \mathrm{E} 4$, and $\mathrm{E} 5$.

The evaluation of genotypes for the yield potential and stability was examined by an average environment coordination method (Yan, 2002). In this study, G10 was showed the highest yield and stable among all genotypes. Thus, G10 was the most desirable genotype and categorized as "ideal" genotype. An ideal genotype is defined as the genotype that produced the highest yielding across test environments, which should have the highest mean performance and be absolutely stable (Yan and Kang. 2003). So far, the soybean breeding program in Indonesia has been focused on developing a high yielding and stable genotype, in accordance with the farmer's preferences. A number of soybean superior varieties with targeted characters have been released (ILETRI, 2015). Superior variety is recognized as an important component of technology which easily adopted, compatible with other technological innovations, environmentally friendly, and sustainable (Jain and Kharkwal, 2012; Chikoye et al., 2017).

In this study, based on the yield components, G10 showed early days to maturity and also has large seed size. The user's preferences are high yielding variety, and also with characteristics of large seed 
size and early days to maturity (Adie et al., 2015). The soybean farmers prefer an earliest maturing variety due to avoid the drought stress and pest infestation through drought escape mechanism (Adie and Krisnawati, 2017; Purwantoro et al., 2017) especially during the dry season. Early maturing variety also useful to increase the cropping index especially in regions with limited water availability (ILETRI, 2011). Beside early days to maturity, soybean with large seed size is also desirable for tempeh production (Antarlina et al., 2002; Krisnawati and Adie, 2015). Based on these facts, therefore G10 was potentially developed and introduced as a new cultivar, particularly for tropical regions.

\section{CONCLUSIONS}

The yield performance of soybean was highly influenced by GEI effects. The GGE analysis revealed that Indonesia can be divided into at least four putative mega-environments for soybean production. G10 was suitable with farmers' preference, stable and has higher yield compared with other genotypes, therefore it could be recommended for developing and releasing as new stable and high yielding variety for tropical regions.

\section{ACKNOWLEDGEMENT}

This research was supported by the Indonesian Agricultural Agency for Research and Development (IAARD), Ministry of Agriculture. We thank Arifin for his assistance during the field research.

\section{REFERENCES}

Abady, M.I., A.A.M. El-Emam, S.A.E. Seadh and F.I. Yousof. 2012. Soybean seed quality as affected by cultivars, threshing methods and storage periods. Research Journal of Seed Science, 5: 115-125.

Adie, M.M., A. Krisnawati and G.W.A. Susanto. 2014. Development of high yielding soybean variety with early days to maturity and large seed size. Annual Report. Indonesian Legume and Tuber Crops Research Institutes. Malang.

Adie, M.M., A. Krisnawati and D. Harnowo. 2015. Diversity and clustering of the soybean promising lines in Sleman District, Yogyakarta. Prosiding Seminar Nasional Masyarakat Biodiversitas Indonesia, 1: 787-791.

Adie, M.M., A. Krisnawati dan G.W.A. Susanto. 2013. Genotype $\times$ environment interactions, yield potential and stability of black soybean promising lines. Berita Biologi, 12 (1): 79-86.

Adie, M.M. and A. Krisnawati. 2017. Clustering of high-yielding and early-maturing soybean genotypes. In: Taufik T et al. (eds), pp.13-19. Proceedings of the 2nd International Conference on Sustainable Innovation (ICoSI) 2014. Springer, Singapore.

Alghamdi, S.S. 2009. Yield stability of some soybean genotypes across diverse environments. Pakistan Journal of Biological Sciece, 7 (12): 2109-2114.

Amira, J.O., D.K. Ojo, O.J. Ariyo, O.A. Oduwaye and M.A. Ayo-Vaughan. 2013. Relative discriminating powers of GGE and AMMI models in the selection of tropical soybean (Glycine max L. Merr.) genotypes. African Crop Science Journal, 21: 67-73.

Antarlina, S.S., J.S. Utomo, E. Ginting and E. Nikkuni. 2002. Evaluation of Indonesian soybean varieties for food processing. In: Rahmianna AA, Nikkuni S (Eds.). Soybean production and postharvest technology for innovation in Indonesia, Malang: Proceedings of RILETJIRCAS Workshop on Soybean Research, p. 58-68.

Asfaw, A., F. Alemayehu, F. Gurum and M. Atnaf. 2009. AMMI and SREG GGE biplot analysis for matching varieties onto soybean production environments in Ethiopia. Science Research Essays, 4: 1322-1330.

Atnaf, M., S. Kidane, S. Abadi and Z. Fisha. 2013. GGE biplots to analyze soybean multi-environment yield trial data in north Western Ethiopia. Journal of Plant Breeding and Crop Science, 5 (12): 245-254.

Baker, R.J. 1988. Tests for crossover genotype $\times$ environment interactions. Canadian Journal of Plant Science, 68: 405-410.

Bhartiya, A., J.P. Aditya, K. Singh, Pushpendra, J.P. Purwar and A. Agarwal. 2017. AMMI \& GGE biplot analysis of multi environment yield trial of soybean in North Western Himalayan state Uttarakhand of India. Legume Research, 40 (2): 306-312.

Brar, K.S., P. Singh, V.P. Mittal, M.L. Jakhar, Y. Yadav, M.M. Sharma, U.S. Shekhawat and C. Kumar. 2010. GGE biplot analysis for visualization of mean performance and stability for seed yield in Taramira at diverse locations in India. Journal of Oilseed Brassica, 1(2): 66-74.

Bueno, R.D., L.L. Borges, K.M.A. Arruda, L.L. Bhering, E.G. Barros and M.A. Moreira. 2013. Genetic parameters and genotype $\times$ environment interaction for productivity, oil and protein content in soybean. African Journal of Agricultural Research, 8 (38): 4853-4859.

Chikoye, D., T. Gondwe and N. Nhamo. 2017. Smart Technologies for Sustainable Smallholder 
Agriculture: Upscaling in Developing Countries. Academic Press. 330p.

Choi, D.H., H.Y. Ban, B.S. Seo, K.J. Lee and B.W. Lee. 2016. Phenology and seed yield performance of determinate soybean cultivars grown at elevated temperatures in a temperate region. PLoS ONE 11(11): 1-18.

Cravero,V., M.A. Esposito, Anido, S.M. Garcia and E. Cointry. 2010. Identification of an ideal test environment for asparagus evaluation by GGE-biplot analysis. Australian Journal of Crop Science, 4 (4): 273-277.

Eberhart, S.A. and W.A. Russell. 1966. Stability parameters for comparing varieties. Crop Science, 6: 36-40.

Fan, X.M., M. Kang, H. Chen, Y. Zhang, J. Tan and C. Xu. 2007. Yield stability of maize hybrids evaluated in multi-environment trials in Yunnan, China. Agronomy Journal, 99:220-228.

Farshadfar, E., M.M. Poursiahbidi and M. Jasemi. 2012. Evaluation of phenotypic stability in bread wheat genotypes using GGE-biplot. International Journal of Agricultural Crop Science, 4 (13): 904-910.

Finlay, K.W. and G.N. Wilkinson. 1963. The analysis of adaptation in plant breeding programme. Australian Journal of Agricultural Research, 14: 742-754.

Gauch, H.G. and R.W. Zobel. 1996. AMMI analysis of yield trials. In Kang MS, Gauch HG (Eds.). Genotype-by-Environment Interaction. CRC Press, Boca Raton. New York, United States of America.

Gauch, H.G. 1992. Statistical analysis of regional yield trials: AMMI analysis of factorial designs. Elsevier Science Pub. Amsterdam, Netherland.

Gauch, H.G. 2006. Statistical analysis of yield trials by AMMI and GGE. Crop Science, 46: 1488-1500.

Gedif, M., D. Yigzaw and G. Tsige. 2014. Genotypeenvironment interaction and correlation of some stability parameters of total starch yield in potato in Amhara region. Etiopia Journal of Plant Breeding and Crop Science, 6 (3): 31-40.

Gurmu, F., M. Hussein and G. Alemaw. 2009. Genotype $x$ environment interactions and stability of soybean for grain iyeld and nutrition quality. African Crop Science Journal, 17 (2): 87-99.

Hagos, H.G. and Abbay. 2013. AMMI and GGE Biplot analysis of bread wheat genotypes in the northern part of Ethiopia. Journal of Plant Breeding and Genetics, 1: 12-18.

Iletri. 2011. Soybean Improved Variety. Indonesian Legumes and Tuber Crops Research Institute.
PENAS XIII Special Edition, 18 June 2011, $2 \mathrm{pp}$.

Iletri. 2015. Description of Soybean Improved Varieties. Indonesian Legumes and Tuber Crops Research Institute. $87 \mathrm{p}$.

Jain, H.K. and M.C. Kharkwal. 2012. Plant Breeding: Mendelian to Molecular Approaches. Springer Science \& Business Media. 811p.

Jandong, E.A., M.I. Uguru and B.C. Oyiga. 2011. Determination of yield stability of seven soybean (Glycine max) genotypes across diverse soil pH levels using GGE biplot analysis. Journal of Applied Bioscience, 43:2924-2941.

Kandil, A.A., A.E. Sharief, A.R. Morsy and A.I.M. El-Sayed. 2012. Performance of some promising genotypes of soybean under different planting dates using Biplots analysis. Journal of Basic \& Applied Science, 8: 379-385.

Kaya, Y., M. Akcura and S. Taner. 2006. GGE biplot analysis of multi-environment yield trials in bread wheat. Turkish Journal of Agriculture and Forestry, 30: 325-337.

Krisnawati, A. and M.M. Adie. 2015. Selection of soybean genotypes by seed size and its prospects for industrial raw material in Indonesia. Procedia Food Science, 3: $355-363$.

Kumar, A., S. Kumar, C. Kapoor, R. Bhagawati, A. Pandey, and A. Pattanayak. 2014. GGE biplot analysis of genotype $\times$ environment interaction in soybean grown in NEH regions of India. Environmental Ecology, 32 (3A): 1047-1050.

Kuswantoro, H. 2016. Potential yield of acid-adaptive soybean promising lines in ultisols of Tanah Laut Regency, South Kalimantan Province, Indonesia. BIOTROPIA, 23 (1): 52-57.

Liu, X.B. and S.J. Herbert. 2002. Fifteen years of research examining cultivation of continuous soybean in Northeast China. Field Crops Research, 79:1-7.

Luo, J., Y.B. Pan, Y. Que, H. Zhang, M.P. Grisham and L. Xu. 2015. Biplot evaluation of test environments and identification of megaenvironment for sugarcane cultivars in China. Scientific Reports, 5:15505.

Oldeman, L.R. 1974. An agroclimatic classification for evaluation of cropping systems 1974 in Southeast Asia. In Report of the FAO/UNDP International expert consultation on the use of improved technology for food production in raifed areas of tropical Asia. Annex III, 1-18, FAO, Rome.

Perkins, J.M. and J.L. Jinks. 1968. Environmental and genotype-environmental component of variability. III. Multiple lines and crosses. Heredity, 23: 339-356. 
Purwantoro, Suhartina, N. Nugrahaeni and A. Sulistyo. 2017. Response of soybean genotypes introduced from South Korea to drought stress during reproductive stage. Biodiversitas, 18: 15-19.

Rakshit, S., K.N. Ganapathy, S.S. Gomashe, A. Rathore, R.B. Ghorade, M.V.G. Kumar, K. Ganesmurthy, S.K. Jain, M.Y. Kamtar, J.S. Sachan, S.S. Ambekar, B.R. Ranwa, D.G. Kanawade, M. Balusamy, D. Kadam, A. Sarkar, V.A. Tonapi and J.V. Patil. 2012. GGE biplot analysis to evaluate genotype, environment and their interactions in sorghum multi-location data. Euphytica, 185: 465-479.

Rao, P.S., P.S. Reddy, A. Rathore, B.V. Reddy and S. Panwar. 2011. Application GGE biplot and AMMI model to evaluate sweet sorghum (Sorghum bicolor) hybrids for genotype $\times$ environment interaction and seasonal adaptation. Indian Journal of Agricultural Science, 81 (5): 438-44.

Samonte, S.O., L.T. Wilson, A.M. McClung and J.C. Medley. 2005. Targeting cultivars onto rice growing environments using AMMI and SREG GGE biplot analyses. Crop Science, 45:2414-2424.

Tonk, F.A., E. Ilker and M. Tosun. 2011. Evaluation of genotype $\times$ environment interactions in maize hybrids using GGE biplot analysis. Crop Breeding and Applied Biotechnology, 11: $1-9$

Ullah, H., I.H. Khalil, Durrishahwar, Iltafullah, I.A. Khalil, M. Fayaz, J. Yan and F. Ali. 2012. Selecting high yielding and stable mungbean [Vigna radiata (L.) Wilczek] genotypes using GGE biplot techniques. Canadian Journal of Plant Science, 92: 951-960.

Yan, W., P.L. Cornelius, J. Crossa and L.A. Hunt. 2001. Two types of GGE biplots for analysis of multi- environment trial data. Crop Science, 41: 565-663.

Yan, W., L.A. Hunt, Q. Sheng and Z. Szlavnies. 2000. Cultivar evaluation and mega-environment investigation based on GGE biplot. Crop Science, 40: 597-605.

Yan, W., M.S. Kang, B. Ma, S. Woods and P.L. Cornelius. 2007. GGE biplot vs. AMMI analysis of genotype-by-environment data. Crop Science, 47: 643-655.

Yan, W. and M.S. Kang. 2003. GGE biplot analysis: a graphical tool for breeders, geneticists and agronomist. CRC Press, Boca Raton, FL. $271 \mathrm{pp}$

Yan, W. and N. Tinker. 2006. Biplot analysis of multilocation trail data: principles and applications. Canadian Journal of Plant Sciece, 86: 623-645.

Yan, W. 2001. GGE biplot- A windows aplication for graphical analysis of multienvironment trial data and other types of two-way data. Agronomy Journal, 93: 1111-1118.

Yan, W. 2002. Singular value partitioning in biplot analysis of multienvironment trial data. Agronomy Journal, 94: 990-996. 